Trinity College

Trinity College Digital Repository

Faculty Scholarship

$7-2014$

Higher Education and World Politics

Isaac Kamola

Trinity College, isaac.kamola@trincoll.edu

Neema Noori

Follow this and additional works at: https://digitalrepository.trincoll.edu/facpub

Part of the Higher Education Commons 


\section{Higher Education and World Politics}

\section{Introduction}

\author{
Isaac Kamola, Trinity College \\ Neema Noori, University of West Georgia
}

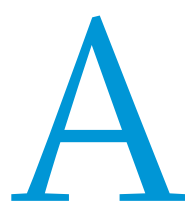

$s$ part of the postconflict reconstruction for Iraq, one that included the rebuilding of hospitals, bridges, water treatment plants, and other pieces of vital infrastructure, the US government earmarked considerable resources for also rebuilding the country's higher education system. Overseen by the Pentagon's Office for Reconstruction and Humanitarian Assistance, the US Department of State and the United States Agency for International Development (USAID) announced a plan to give \$20-million to American universities that developed programing with Iraqi universities. The Iraqi Development Fund allocated another \$37 million to help rebuild Iraq's 43 universities and colleges (Castillo 2003a; 2003b; Torres and Rhoads 2006). Similarly, in Afghanistan, USAID announced a $\$ 15$ million grant to establish the American University of Afghanistan in Kabul, deciding to break ground on a private, English-language university rather than allocate similar funds to rebuild Afghanistan's dilapidated state university system (Zoepf 2006).

The inclusion of higher education as part of postconflict reconstruction is not an isolated event but rather one poignant example of the growing role higher education plays in shaping world politics. For the last two decades higher education around the world has undergone profound transformations. Since 1995 the number of young people receiving higher education in Organization for Economic Cooperation and Development (OECD) countries has increased by $25 \%$, with an average of $59 \%$ of young adults in these countries now attending postsecondary institutions (OECD 2011, 308). This boom is even more pronounced in many non-OECD countries. For example, university graduation rates quadrupled in Malaysia and doubled in Chile and Thailand between 1995 and 2003 (UNESCO 2005, 44). ${ }^{1}$ World expenditure on higher education now stands at \$2 trillion (Santos 2006, 68).

This rapid growth in university education has many contributing factors. Not only is there a growing recognition that economic competitiveness requires a highly educated workforce, but international trade law now protects higher education itself as a commodity that can be bought and sold in a world market. In 1995 education became classified as one of 12 services protected under the World Trade Organization's General Agreement on Trade in Services (GATS). This agreement reduced various "trade barriers" to higher education, making it easier to offer online courses in foreign countries, to facilitate branch and satellite campuses, and to enable the movement of students "services, professors, and researchers" (Santos 2006, 69-73). As a result, higher education has emerged as an important sector of the economy for many countries. For example, in Australia money brought in by the massive influx of foreign students constitutes the country's third largest export (Wildavsky 2010, 24); between 1990 and 2000, foreign students contributed roughly $£ 8$ billion to the British economy (Torres and Rhoads 2006, 18); higher education is now the United State's fifth largest export service, yielding $\$ 12$ billion a year (Ross 2008, 217). In terms of the world economy, higher education now represents a $\$ 40$ and $\$ 50$ billion industry, only slightly less than the international market for financial services (Ross 2008, 211).

During this same period, Qatar, Dubai, Saudi Arabia, and other oil-exporting Middle Eastern countries have identified higher education as a viable avenue for economic diversification. Drawing on their vast wealth, these countries have collectively engaged in massive projects building new universities and sprawling higher education complexes, including King Abdullah University of Science and Technology (Saudi Arabia), Knowledge Village (United Arab Emirates) and Education City (Qatar) - the latter two hosting branch campuses of prestigious US and European universities (Wildavsky 2010, Chapter 2). New York University similarly received a $\$ 100$ million gift to establish a branch campus in Abu Dhabi (Ross 2008, 217). The Rwandan government recently promised \$95 million over 10 years to Carnegie Mellon University to open a branch campus in Kigali (Wilhelm 2011).

In addition to becoming major engines for economic development, universities also play a vital role in training and socializing transnational elites. For example, the newly elected Iranian President Rouhani earned his $\mathrm{PhD}$ from Caledonian University in Scotland, and his chief of staff holds a PhD in economics from George Washington University. Political leaders from around the world routinely send their children to be educated at elite American and European universities: Ayatollah Khomeini's granddaughter is currently enrolled as a student in Canada, and the daughter of China's President Xi Jinping attends Harvard University (Kaiman 2013). In 2011 the director of the London 
School of Economics, Sir Howard Davies, resigned after it became widely known that, in addition to personally advising Libya's sovereign wealth fund, the school under his watch had accepted a $£_{3}$.6-million contract to train Libyan elites as well as a $£ 1$.5-million donation from a charity run by Muammar Qaddafi's son to fund the center on global governance (Guttenplan 2011; Vasagar and Syal 2011). Saif al-Islam had earlier received his PhD from the LSE. complicate things, the power that institutions of higher education exert, and the expertise they produce, often accumulates unnoticed over long periods, becoming evident only in contexts quite differently than previously imagined. As such, whereas scholars of international relations and world politics should treat the university as an important political actor in the contemporary world, we often lack the theoretical and empirical resources to do so.

\section{Whereas scholars of international relations and world politics should treat the university as an important political actor in the contemporary world, we often lack the theoretical and empirical resources to do so.}

Despite being central to many different dimensions of world politics-including geopolitical strategy, international trade, economic development, and elite socialization-higher education remains almost completely absent from scholarly conversations about international relations and world politics. On the one hand, social scientists have long examined the mechanisms by which institutions, norms, cultures, and organizational practices are transferred around the world. A vast and vibrant literature now exists, for example, on the effects of transnational corporations (TNCs), foreign direct investment, and international nongovernmental organizations (INGOs) on international politics. On the other hand, comparatively little work examines how universities-and institutions of higher education more generally-serve as important nodes of international interconnection.

This absence is not particularly surprising given that universities are an exceptionally ambiguous and complicated political actor. Most universities present themselves as institutions largely divorced from both the rough-and-tumble of the market as well as the partisan constraints of political life. Similarly, scholars who inhabit these colleges and universities often tacitly reproduce the supposed analytical distance between the bucolic "ivory tower" and the complicated and messy world that becomes their object of study. However, despite a desire to maintain the distinction between university and "real world," universities are engaged in shaping all aspects of economic and political life in many ways. First, universities-including the students, faculty, and staff that inhabit them-are often closely aligned with various national and international economic and political positions. After all, universities train civil servants, public intellectuals, business leaders, and even soldiers. Second, they receive funding from governments and corporations to pursue particular lines of research and often consult for governments, businesses, and international organizations. Therefore, universities are commonly treated as engines of national and local economic growth, serving parochial audiences while also seeking to embody a global cosmopolitan identity. Furthermore, most universities increasingly find themselves acting as commercial entities, forced to compete against each other for limited revenue and talent. Third, while universities serve as important nodes in world economy, they also have emerged as vocal sites of resistance to existing economic and political policies. To further
This symposium is a first step to situate universities as actors in world politics. This project began as a series of panels organized in consecutive years (2011 through 2014) at the International Studies Association's general meetings. The result has been a transnational conversation among scholars in North and South America, Asia, and Europe about how the social science literature-and that of international relations and world politics in particular-might better understand and theorize the university as a significant "global" actor. Over the years, panelists have presented research on subjects as varied as the soft-power effects of American universities in the Middle East, global ranking schemes as a form of global governance, and the internationalization of higher education reform in post-apartheid South Africa. These conversations have coalesced around several themes concerning how universities might be conceptualized as important actors in world politics.

The first theme involves seeing the university as a paradigmatic example of the circulation of people, money, ideas, and field expertise around the world. Studies of globalization, for example, often focus on cities, financial hubs, international institutions, and outsourced production facilities as their case studies. Several scholars in this symposium see universities as useful opportunities to study the processes of globalization, internationalization, and integration. The worldwide harmonization of curricular offerings, governance structures, pedagogical practices, and funding models suggest that tertiary education is becoming more uniform around the world (Frank and Gabler 2006; Schofer and Meyer 2005). Whether due to the ascendance of the American model of education, global ranking systems, transnational governance regimes, or economic globalization, standardization and homogenization is a clear trend.

In addition to helping explain the isomorphic trends within international interconnection, studying universities as sites of world politics, the second theme, also makes visible the heterogeneous and asymmetrical ways in which the contemporary world is being drawn together. International ranking schemes like the Times Higher Education and Academic Ranking of World Universities (Shanghai Jiao Tong University) frame universities as firms competing within a highly competitive global playing 
field. This playing field, however, is by no means level. First of all, the term "university" itself applies to a broad, diverse body of institutions, with considerable variation across types. Universities can be public or private, large or small, wealthy or impoverished, elite or peripheral, for-profit or not-for-profit, as well as graduate and undergraduate focused, research or teaching, and two-year or four-year institutions. Similarly, universities in Africa, Asia, or South America may look and function very differently than institutions in France, Australia, or the United States, which themselves substantially differ. The world of higher education, therefore, might be understood as a point of tension between the isomorphic trends toward a "world culture" of higher education and the diverse lived realities, national and statist agendas, historical and cultural parameters, and cultural terrains. Universities, in other words, might be thought as points of considerable "friction" (Tsing 2005).

The third theme examines whether universities primarily reproduce existing social and power relations or whether they provide important spaces of resistance and transformation. On the one hand, students have historically been important political actors, and universities around the world from Johannesburg to Belgrade have served as havens for subversive views and cultivating domestic and global contestation. On the other hand, the recent remaking of higher education may have transformed universities into primarily practical institutions of economic development, career training, and marketable research. Several contributors argue that, given the increased marketization of higher education, we should be skeptical of the idea that today universities can claim institutional autonomy, or even basic standards of academic freedom.
These critiques, however, became materially harder to sustain as the World Bank enforced structural adjustment policies that crippled many university systems across the continent. As such, Kamola both laments the loss of local stocks of knowledge and argues that a newly invigorated African University might provide insights into the current crisis facing higher education.

In the context of the Middle East, Neema Noori's piece questions the ability of institutions that adopt the American model of education (including branch campuses) to advance academic freedom in the region. Noori argues that critics of George Mason University, Northwestern University, and New York University, who contend that these universities have sacrificed Western academic values for financial gain, are justified in their skepticism. However, it is wrong to assume that branch campuses are completely inhospitable to academic freedom or that they cannot fulfill the promise of reproducing the liberal arts experience in the Persian Gulf. Noori contends that Western branch campuses are somewhat shielded from the free-speech restrictions imposed on regional universities in the Middle East. Because most of the prestigious branch campuses are analogous to high-end academic resorts for global elites, these universities draw from a small pool of student and faculty applicants; therefore, their abilities to engage a wider, more representative public remains limited. Narrow curricular offerings in branch campuses also restrict academic freedom for students who have a spartan menu of course offerings available, making it less likely that controversial subjects are taught. In contrast, privately owned American-style universities face a different problem: they do not provide tenure, and,

\section{Because most of the prestigious branch campuses are analogous to high-end academic resorts for global elites, these universities draw from a small pool of student and faculty applicants; therefore, their abilities to engage a wider, more representative public remains limited.}

Each contribution to this symposium examines these three themes in several ways by using the experience of universities in one world region as an entrée into thinking more broadly about how universities might be considered as actors in world politics. Isaac Kamola argues that rather than seeing African universities as not-yet-global, instead they might be understood as the paradigmatic example of "the global university." Western influence on tertiary education in Africa did not end with colonialism and extends beyond cooperative ventures among universities, such as branch campuses and double-degree programs. In the 1980s, for example, the World Bank recommended that Africa prioritize funding for primary education at the expense of higher education. This advice came on the heels of two decades during which African countries invested heavily in the development of university systems to promote economic development and strengthening local stocks of its indigenous intellectual capital. During this period African intellectuals questioned both the basic assumptions of Western academic knowledge as well as its relevance to the particular problems facing Africa. although they offer a broader array of courses, the absence of tenure discourages faculty from engaging audiences outside campus.

Meng-Hsuan Chou's contribution tackles a related set of concerns, but in the context of European integration. The challenge for European policy formation-including policy around higher education-includes adopting international standards and ensuring compliance across a wide political and geographical space. In Europe, the challenge has been to create an open space for the free movement of European research scientists and students. With the adoption of the Eurozone, and the lowering of border controls on the movement of people and goods between countries, the next major European Union initiative is to unlock barriers to the transnational flow of ideas between member states. These Eurozone policies are based on the assumption that an academic labor market is waiting to be unleashed when the correct set of policy instruments are provided. Drawing on participant observations from key policy meetings, Chou analyzes the decentralized processes implemented to move Europe toward 
a "Europe of Knowledge." She documents the formidable barrierspolitical, organizational, and cultural-impeding progress toward integration. She refers to the resulting decentralized strategy, which bypasses central control and empowers university administrators, as establishing the "Republic of Research Administrators" that must go hand-in-hand with the creation of the "Republic of Letters."

Universities are often important actors during times of political and transnational unrest. Martina Vukasovic, while assessing a period of institutional upheaval in postcommunist Yugoslavia, shows that in 1998 the Serbian government introduced several dramatic reforms, including the wholesale replacement of the University of Belgrade's leadership. Ironically, in the end, changes that increased the central government control of higher education were justified on the grounds that they would modernize Serbia's higher education system. Vukasovic's contribution shows that despite serving as a hotbed for protest activity during the tumultuous decade following the breakup of Yugoslavia, Serbian universities did not formally take political stances or act as political agents. This insight underscores the need to look beyond the university as an autonomous and coherent global actor, examining it instead as comprised of a diverse set of competing individual and group actors, including administrators, faculty, and students.

Despite evidence to suggest convergence of higher education policies, countervailing movements propose alternative ways of organizing university systems. Salvador Peralta and Thiago Pacheco address the education reforms enacted by newly elected leftist parties in Latin America. Designed in opposition to the neoliberal agendas of the previous two decades, reforms under Lula da Silva in Brazil, Ricardo Lagos, and Michelle Bachelet in Chile, Hugo Chavez in Venezuela, and others have sought to restore funding to public universities, broaden access to underserved populations, and reduce tuition costs. However, with the exception of Venezuela, most of these ambitious reforms remain unfulfilled. Peralta and Pacheco demonstrate that the neoliberal economic policies of previous governments have proven particularly difficult to roll back, even when the government articulates an alternative vision for university education.

Rasmus Bertelsen's contribution demonstrates that in the late nineteenth century, a full century before Western INGOs became active in the Middle East and East Asia, ChristianAmerican missionaries helped found multiple universities in both regions. His research on these early experimental outposts suggests that they played an underacknowledged role in advancing American interests in the region. But, aside from their soft-power utility, these institutions served as useful interlocutors helping to translate ideas, promote understanding, and enable transfers of knowledge. This relationship, as Bertelsen compellingly argues, was not one-dimensional because Chinese-American and Middle Eastern-American universities also shaped American foreign policy in ways that served their host countries' national interests. In other words, these universities engaged in "reverse soft-power." Bertelsen contends that these reciprocal lines of influence underscore the multidimensional and multidirectional power of transnational universities.

We hope that this symposium begins a more widespread conversation among social scientists about the role our colleagues, our students, and our institutions play in the making of world politics. Doing so will not only provide a more robust understanding of universities as political and economic institutions, but also expand the conceptual contours of what counts as "world politics." -

\section{NOT ES}

1. Similar growth rates can be seen around the world. For example, between 2000 and 2007 enrollment rates jumped from $51 \%$ to $91 \%$ in Greece; $37 \%$ to $69 \%$ in Hungary, $46 \%$ to $73 \%$ in Iceland, $28 \%$ to $47 \%$ in Kazakhstan, $34 \%$ to $54 \%$ in Lebanon, $50 \%$ to $76 \%$ in Lithuania, $50 \%$ to $67 \%$ in Poland, $78 \%$ to $95 \%$ in Korea, $24 \%$ to $58 \%$ in Romania, $19 \%$ to $31 \%$ in Tunisia, $23 \%$ to $36 \%$ in Turkey; $49 \%$ to $76 \%$ in Ukraine, $34 \%$ to $64 \%$ in Uruguay, and $28 \%$ to $52 \%$ in Venezuela (UNESCO 2007, 193-98).

\section{R E F E R E N C E S}

Castillo, Daneil Del. 2003a. "In Iraq, Daunting Tasks for Higher Education." Chronicle of Higher Education 50 (3): A37.

Castillo, Daniel Del. 2003b. "Preparing to Rebuild Iraq's Universities.” Chronicle of Higher Education 49 (33): A42.

Frank, David John, and Jay Gabler. 2006. Reconstructing the University: Worldwide Shifts in Academia in the 2oth Century. Palo Alto, CA: Stanford University Press.

Guttenplan, D. D. 2011. "London Econoimcs School to Investigate Dealings With Libya." New York TImes, March 3. http://www.nytimes.com/2011/03/o5/ world/europe/o5degree.html?_r=o

Kaiman, Jonathan. 2014. "Xi Jinping: Chinese Rule Who's a Riddle to the World." The Guardian, November 30. http://www.theguardian.com/ theobserver/2013/dec/01/xi-jinping-china-leader

OECD. 2011. "Education at a Glance 2011: OECD Indicators." OECD Publishing http://dx.doi.org/10.1787/eag-2011-en.

Ross, Andrew. 2008. "Global U.” In The University Against Itself: The NYU Strike and the Future of the Academic Workplace, ed. M. Krause, M. Nolan, M. Palm, and A. Ross. Philadelphia: Temple University Press.

Santos, Boaventura de Sousa. 2006. "The University in the 21st Century: Toward a Democratic and Emancipatory University Reform." In The University, State, and Market: The Political Economy of Globalization in the Americas, ed. R. A. Rhoads and C. A. Torres. Palo Alto, CA: Stanford University Press.

Schofer, Evan, and John W. Meyer. 2005. "The Worldwide Expansion of Higher Education in the Twentieth Century." American Sociological Review 70: 898-920.

Torres, Carlos Alerto, and Robert A. Rhoads. 2006. "Introduction: Globalization and Higher Education in the Americas." In The University, State, and Market: The Political Economy of Globalization in the Americas, ed. R. A. Rhoads and C. A. Torres. Palo Alto, CA: Stanford University Press.

Tsing, Anna Lowenhaupt. 2005. Friction: An Ethnography of Global Connection. Princeton, NJ: Princeton University Press.

UNESCO. 2005. "Education Trends in Perspective: Analysis of the World Education Indicators.” Paris: UNESCO.

Vasagar, Jeevan and Rajeev Syal. 2011. "LSE Head Quits Over Gaddafi Scandal," The Guardian, March 3. http://www.theguardian.com/education/2011/ mar/o3/lse-director-resigns-gaddafi-scandal

Wildavsky, Ben. 2010. The Great Brain Race: How Global Universities Are Reshaping the World. Princeton, NJ and Oxford: Princeton University Press.

Wilhelm, Ian. 2011. "Carnegie Mellon U. to Open Campus in Rwanda, A Mileston for Africa." Chronicle of Higher Education 58 (5): A23.

Zoepf, Katherine. 2006. "American Higher Education Comes to Kabul." Chronicle of Higher Education 51 (21): A46-7. 


\section{SYMPOSIUM CONTRIBUTORS}

Rasmus Gjedssø Bertelsen is an assistant professor of European studies and international relations at Aalborg University, Denmark. His research examines transnational flows of knowledge, talent, capital, and power between the spheres of higher education, business, civil society, and government. He has written about these questions in Foreign Policy Analysis, Strategic Insights, Revue des mondes musulmans et de la Méditerranée, Global Society, International Journal of Business and Globalisation, Journal of China and International Relations, Arctic Yearbook, and a number of edited volumes. He can be reached atRasmus@cantab.net.

Meng-Hsuan Chou is Nanyang Assistant Professor in public policy and global affairs at Nanyang Technological University NTU, Singapore. She is currently researching how governments in Asia, Europe, and North America compete for foreign talent in a globalized world and how scholarly networks are organized across time. Her work, which lies at the intersection of public policy, regionalism, and international relations, has been published in the Journal of European Public Policy, Journal of Contemporary European Research, Perspectives on European Society and Politics, and several edited volumes. She recently coedited Building the Knowledge Economy in Europe (2014, Elgar) - the first volume to compare European research and higher education policy. She can be reached atHsuan@cantab.net.

Isaac Kamola is an assistant professor of political science at Trinity College, Hartford, Connecticut. His research examines how the material transformation of post-Cold War higher education in the United States and Africa inform how the world came to be imagined as "global." His scholarly work has appeared in International Political Sociology, British Journal of Politics and International Relations, Journal of Higher Education in Africa, Third World Quarterly, Polygraph, and Transitions as well as numerous edited volumes. He can be reached at ikamola@trincoll.edu.

Neema Noori is an associate professor of sociology at the University of West Georgia, Carrollton, Georgia. His scholarly work has appeared in the International Journal of Culture, Politics and Society, the Annual Review of Political and Military Sociology, and Central Asia Survey. He can be reached atnnoori@ westga.edu.

Thiago Pezzuto Pacheco is an independent consultant specializing in public policy and government relations currently based in Rio de Janeiro, Brazil. He holds a master's of public policy from the Hertie School of Governance and a master's in business economics from the Federal University of Rio de Janeiro, where he also earned a bachelor's degree in law. His research interests and expertise include regional integration, comparative public policy, public management, political parties and electoral systems, corruption and governance, and education policy. He can be reached at pezzutothiago@gmail.com.

J. Salvador Peralta is assistant professor and chair of the political science and planning department at the University of West Georgia, Carrollton, Georgia. His comparative research explores how institutions and cultures impact electoral behavior and policymaking. His most recent work has appeared in Politics and Policy, Administrative Theory and Praxis, and PS: Political Science and Politics. He can be reached atjperalta@westga.edu.

Martina Vukasovic is a postdoctoral researcher affiliated with the Centre for Higher Education Governance at the Ghent University in Belgium. Her research focuses on the diffusion of education policy within the member states of the European Union. She is particularly interested in education governance and reform in the post-communist countries of Europe. Her work has been published in Higher Education, Higher Education Policy, and Quality in Higher Education, as well as several edited volumes. She can be reached atmartina.vukasovic@ugent.be. 